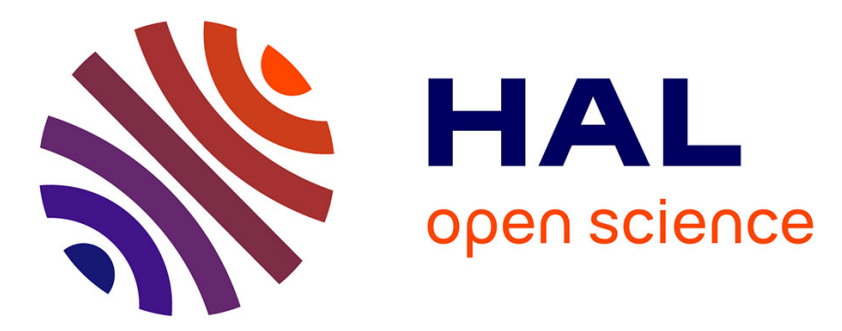

\title{
Photosynthetic activity and productivity of intertidal macroalgae: in situ measurements, from thallus to community scale
}

Aline Migné, Gaspard Delebecq, Dominique Davoult, Nicolas Spilmont, Dominique Menu, François Gévaert

\section{To cite this version:}

Aline Migné, Gaspard Delebecq, Dominique Davoult, Nicolas Spilmont, Dominique Menu, et al.. Photosynthetic activity and productivity of intertidal macroalgae: in situ measurements, from thallus to community scale. Aquatic Botany, 2015, 123, pp.6-12. 10.1016/j.aquabot.2015.01.005 . hal01112117

\section{HAL Id: hal-01112117 https: / hal.sorbonne-universite.fr/hal-01112117}

Submitted on 2 Feb 2015

HAL is a multi-disciplinary open access archive for the deposit and dissemination of scientific research documents, whether they are published or not. The documents may come from teaching and research institutions in France or abroad, or from public or private research centers.
L'archive ouverte pluridisciplinaire HAL, est destinée au dépôt et à la diffusion de documents scientifiques de niveau recherche, publiés ou non, émanant des établissements d'enseignement et de recherche français ou étrangers, des laboratoires publics ou privés. 
Photosynthetic activity and productivity of intertidal macroalgae: in situ measurements, from

\section{thallus to community scale}

Aline Migné ${ }^{1,2, *}$, Gaspard Delebecq ${ }^{3,4,+}$, Dominique Davoult ${ }^{1,2}$, Nicolas Spilmont ${ }^{3,4,5}$, Dominique Menu ${ }^{4}$, François Gévaert ${ }^{3,4}$

1- Sorbonne Universités, UPMC Univ Paris 06, Station Biologique, F-29680 Roscoff, France

2- CNRS, UMR 7144 AD2M, F-29680 Roscoff, France

3- Université Lille1, Univ Lille Nord de France, Station Marine, F-62930 Wimereux, France

4- CNRS, UMR 8187 LOG, F-62930 Wimereux, France

5- Environmental Futures Centre, Griffith University, Gold Coast Campus, QLD 4222, Australia

* corresponding author: migne@sb-roscoff.fr, 33 (0)2 98292531

+ present adress: Université de Bretagne Occidentale, Institut Universitaire Européen de la Mer, F29280 Plouzané CNRS, UMR 6539 LEMAR, F-29280, Plouzané

GD: gasp.delebecq@hotmail.fr

DD: davoult@sb-roscoff.fr

NS: nicolas.spilmont@univ-lille1.fr

DM: dominique.menu@univ-lille1.fr

FG: francois.gevaert@univ-lille1.fr

Individual contribution of authors

AM, GD, DD, NS, FG: Conceived study, performed research, analysed data, wrote paper

DM: Conceived benthic chamber, performed research 


\section{Abstract}

The photosynthetic activity and productivity of four dominant canopy intertidal macroalgae were measured under emersion and immersion, at saturating light levels (PAR $>300 \mu$ mol photons $\mathrm{m}^{-2} \mathrm{~s}^{-1}$ ), and compared at two sites (eastern and western English Channel) in spring and summer. The photosynthetic activity of thalli was measured by the electron transport rate (ETR) using pulseamplitude modulated (PAM) fluorescence and the productivity of individuals and of communities was measured by carbon fluxes in closed chambers. Under emersion, when thalli were still hydrated, the uppermost species Pelvetia canaliculata had higher photosynthetic activity (mean ETR between 327 and $460 \mu \mathrm{mol} \mathrm{e}^{-} \mathrm{m}^{-2} \mathrm{~s}^{-1}$ ) and individual gross productivity (between 60 and $212 \mu \mathrm{mol} \mathrm{C} \mathrm{gDw}^{-1} \mathrm{~h}^{-1}$ ) than the lowermost species Laminaria digitata (mean ETR between 24 and $53 \mu \mathrm{mol} \mathrm{e}-\mathrm{m}^{-2} \mathrm{~s}^{-1}$ and gross productivity between 2 and $38 \mu \mathrm{mol} C \mathrm{gDw}^{-1} \mathrm{~h}^{-1}$ ), whatever the site and season. $P$. canaliculata had higher ETR in air than underwater (averaged $146 \mu \mathrm{mol} \mathrm{e} \mathrm{m}^{-2} \mathrm{~s}^{-1}$ ) and L. digitata had lower ETR in air than underwater (averaged $112 \mu \mathrm{mol} \mathrm{e} \mathrm{m}^{-2} \mathrm{~s}^{-1}$ ), while they exhibited respectively 3 and 5 times higher gross productivity underwater. At the community scale, the low mid-shore zone of Fucus serratus had the highest mean gross productivity under emersion $\left(47 \mathrm{mmol} \mathrm{C} \mathrm{m}^{-2} \mathrm{~h}^{-1}\right)$ while rates were higher for the uppermost than lowermost zone at the eastern site (average 20 and $6 \mathrm{mmol} \mathrm{C} \mathrm{m}$ ${ }^{2} \mathrm{~h}^{-1}$ respectively) and of the same order of magnitude for both zones at the western site (about 30 $\mathrm{mmol} \mathrm{C} \mathrm{m}^{-2} \mathrm{~h}^{-1}$ ). Finally, the variability of under emersion primary productivity among sites and seasons was reduced when the measurements were performed on entire communities compared to isolated individuals of the dominant species.

\section{Key words}

Primary production, Rocky shores, Fucoids, Kelps

\section{Running page head}

Productivity of intertidal macroalgae 


\section{Abbreviations}

A absorption coefficient

DIC dissolved inorganic carbon

DW dry weight

Em emersion

ETR electron transport rate

$F_{\mathrm{m}}{ }^{\prime}$ maximal fluorescence level

Fse Fucus serratus

Fsp Fucus spiralis

$F_{\mathrm{t}}$ fluorescence steady-state level

FW fresh weight

GCP gross community productivity

GP gross productivity

Im immersion

Ld Laminaria digitata

NCP net community productivity

NP net productivity

PAM pulse-amplitude modulated

PAR photosynthetically available radiation

Pc Pelvetia canaliculata

$\mathrm{R}$ respiration

Ro Roscoff

Sp spring

Su summer

TA total alkalinity

Wx Wimereux

$\Phi_{\text {PSII }}$ effective quantum yield of photosystem II 


\section{Introduction}

Rocky shores are frequently dominated by dense populations of macroalgae that exhibit distinct patterns of vertical zonation. On northern hemisphere temperate coasts, this pattern typically consists of the succession of fucoid algae from the high to the low mid shore and of laminarians (or kelps) in the lower shore. The productivity of such seaweed populations has long been shown to be important, ranging from 1 to several $\mathrm{kg} \mathrm{C} \mathrm{m}^{-2} \mathrm{y}^{-1}$ (Mann, 1973). However, these estimations were rather raw and still need to be specified. In particular, the ecological performance of macroalgae has to be measured in situ and at the multi-species community scale to take into account not only the dominating species but all the species as well as their interactions in relevant conditions. Intertidal macroalgae experience two very different environments for photosynthesis, aerial and aquatic. The capacity of species from different shore levels to maintain photosynthesis during emersion periods has long been investigated based on measurements performed on isolated thalli under controlled laboratory conditions (e.g. Johnson et al., 1974; Quadir et al., 1979; Dring and Brown, 1982). Since then, differences between some shallow-water macroalgae species have been shown to be smaller at the communities scale than experiments on single thallus pieces suggested (Binzer and Middelboe, 2005) and an increasing productivity of fucoid assemblages down a shore-height gradient has been shown (Tait and Schiel, 2011). These community-scale measurements were limited, however, to immerged conditions and trends might be different under peculiar conditions of the emersion periods. The present study compares the photosynthetic activity and productivity of thalli of the dominant canopy macroalgae (i.e. the zone-forming species typical of the northern hemisphere temperate shores) and the productivity of the communities, based on in situ measurements performed either during emersion or immersion periods. First, the photosynthetic activity of adult thalli was examined using pulse-amplitude modulated (PAM) fluorescence. This technique, which relies on the variable fluorescence of chlorophyll $a$, is not a direct measurement of photosynthesis but allows an examination of the dynamic properties of photosynthesis in response to environmental changes (Enriquez and Borowitzka, 2010) during the whole tidal cycle (emersion and immersion). 
Second, the productivity of single individual, or several individuals of a single species, was assessed using a closed chamber system. This monospecific approach aimed at understanding the productivity dynamic of each species in response to the environment variation (aerial versus aquatic). Third, the productivity of multi-species communities was assessed using closed chamber systems under emersion. This assemblage-based approach integrated the resource partitioning among canopyforming macroalgae and their sub-canopy assemblages. The aim of the study was to test two hypotheses: (1) the in air versus under water ratio of photosynthetic performance decreases down a shore-height gradient; (2) the variation in photosynthetic performance among dominant canopy species of the shore is reduced when the measurements are scaled up from thallus to community.

\section{Materials and Methods}

\subsection{Target species and study sites}

The target species were the three fucoids Pelvetia canaliculata (the uppermost zone-forming species), Fucus spiralis (the immediately contiguous zone-forming species) and Fucus serratus (the lowermost zone-forming fucoid) and the kelp Laminaria digitata (the lowermost zone-forming species). Two seasons (spring and summer) and two sites, differing for the timing of the tide and for turbidity, were investigated. Measurements were performed at the rocky shore of Wimereux $\left(50^{\circ} 44^{\prime} 48^{\prime \prime} \mathrm{N}-1^{\circ} 35^{\prime} 54^{\prime \prime} \mathrm{E}\right.$, eastern English Channel, France) during spring tides in September 2009 (summer) on the four seaweed communities (P. canaliculata, F. spiralis, F. serratus and L. digitata) and in April 2010 (spring) on three seaweed communities (P. canaliculata, F. spiralis and L. digitata) and at the rocky shore of Roscoff ( $48^{\circ} 43^{\prime} 53^{\prime \prime} \mathrm{N}-3^{\circ} 59^{\prime} 16^{\prime \prime} \mathrm{W}$, western English Channel, France) during spring tides in August 2010 (summer) and in May 2011 (spring) on the uppermost and the lowermost seaweed communities ( $P$. canaliculata and L. digitata). At Wimereux, water turbidity is high and low tides of spring tide occur in the early morning (low tides occurred between 7:30am and 10:00am, UT+2h, for summer measurements and between 7:00am and 8:30am, UT+2h, for spring measurements). At Roscoff, water turbidity is low and low tides of spring tide occur in the early 
afternoon (low tides occurred between 2:00pm and 3:30pm, UT $+2 \mathrm{~h}$, for summer measurements and between 1:30pm and 2:30pm, UT $+2 \mathrm{~h}$, for spring measurements).

\subsection{Light and temperature}

Photosynthetically available radiation (PAR in $\mu$ mol photons $\mathrm{m}^{-2} \mathrm{~s}^{-1}$ ) was measured in air and underwater and recorded every minute using a WinCQ flat sensor (Alec Electronics). Temperature was measured in air and underwater and recorded every minute using a MDS MkV-T sensor (Alec Electronics). Average temperature during the periods of selected measurements was $18^{\circ} \mathrm{C}$ underwater and $20^{\circ} \mathrm{C}$ in the air in summer and $11^{\circ} \mathrm{C}$ underwater and $14^{\circ} \mathrm{C}$ in the air in spring, at Wimereux. It was $17^{\circ} \mathrm{C}$ underwater and $27^{\circ} \mathrm{C}$ in the air in summer and $14^{\circ} \mathrm{C}$ underwater and $22^{\circ} \mathrm{C}$ in the air in spring, at Roscoff.

\subsection{Fluorescence}

In vivo chlorophyll fluorescence properties were measured in situ using a submersible PAM fluorometer (Diving PAM, Walz). The fluorescence signal was always taken from the middle of the frond in the same place for three haphazardly-selected and marked individuals of the target species. The effective quantum yield of photosystem II ( $\left.\Phi_{\text {PSII }}\right)$ was measured under ambient light at different stages of the tidal cycle. The fiber optic was mounted in a home-made transparent Plexiglas holder applied to one side of the thallus in such a way that the distance between the fiber optic and the algal tissue was constant and standard. The fiber optic forms a $60^{\circ}$ angle with the sample, avoiding shading or darkening. $\Phi_{\mathrm{PSII}}$ was calculated as $\left(F_{\mathrm{m}}{ }^{\prime}-F_{\mathrm{t}}\right) / F_{\mathrm{m}}{ }^{\prime}\left(\right.$ Genty et al., 1989), where $F_{\mathrm{m}}{ }^{\prime}$ is the maximal fluorescence level measured during a single saturating light pulse $(0.8 \mathrm{~s})$ for light-adapted samples, and $F_{\mathrm{t}}$ is the fluorescence steady-state level immediately prior to the flash. Then, the electron transport rate (ETR in $\mu \mathrm{mol}$ electrons $\mathrm{m}^{-2} \mathrm{~s}^{-1}$, here after referred to as $\mu \mathrm{mol} \mathrm{e}^{-} \mathrm{m}^{-2} \mathrm{~s}^{-1}$ ) was estimated using the following equation:

$E T R=\Phi_{P S I I} \times P A R \times 0.5 \times A$

where PAR is the photosynthetically available radiation (in $\mu \mathrm{mol}$ photons $\mathrm{m}^{-2} \mathrm{~s}^{-1}$ ) , 0.5 is a correction factor based on the assumption that the incident photons are absorbed equally by the pigments of 
the two photosystems and $A$ is the absorption coefficient determined in the laboratory using an integrating sphere (ISR-240A, Shimadzu). The absorption coefficient varied between 0.93 and 0.97 according to the species and season.

\subsection{Carbon fluxes}

Productivity of single or several individuals (depending on the size of the species) was measured using a benthic chamber placed on the shore at the target species level. The system was made of a transparent closed Perspex dome tightly sealed on the polyvinylchloride (PVC) base of the chamber and enclosed a volume of 35.3 L. During immersion periods, an electronic management system controlled three external pumps; two pumps ensured the rapid and constant homogenization of the media while the third one ensured the renewal of the media by flushing ambient seawater between two consecutive incubations (Gévaert et al., 2011). pH was measured with a WTW sentix 41 probe (Multi 350i, WTW) and monitored every minute during 10 min incubations. Seawater was collected from inside the benthic chamber using a $100 \mathrm{ml}$ syringe, then passed through cellulose acetate membrane filters $(0.8 \mu \mathrm{m})$ and spiked with $\mathrm{HgCl}_{2}$ pending potentiometric laboratory determination of total alkalinity (Millero et al., 1993) on 3 subsamples of $20 \mathrm{ml}$. The dissolved inorganic carbon (DIC) concentration of seawater was calculated from the $\mathrm{pH}$, total alkalinity (TA), temperature and salinity according to Strickland \& Parsons (1972) and using the formula given in Oviatt et al. (1986). DIC flux

$\left(\mu \mathrm{mol} \mathrm{h}{ }^{-1}\right)$ was calculated as the difference between the final and the initial concentrations after the linearity of the $\mathrm{pH}$ (corrected from temperature) change has been checked. During emersion, inorganic carbon fluxes were measured in the benthic chamber using closed air circuit for $\mathrm{CO}_{2}$ analysis (Migné et al., 2002). Changes in air $\mathrm{CO}_{2}$ concentration (ppm) were measured in the chamber with a $\mathrm{CO}_{2}$ infrared gas analyser (LiCor Li-6251) and recorded with a data logger (LiCor Li-1400) at 15 s intervals during incubations of about 10 minutes duration. $\mathrm{CO}_{2}$ fluxes $\left(\mu \mathrm{mol} \mathrm{h}{ }^{-1}\right)$ were calculated from the slope of $\mathrm{CO}_{2}$ concentration against time assuming a molar volume of $22.4 \mathrm{~L}$ at standard temperature and pressure. The benthic chamber was opened between two consecutive incubations 
to renew the ambient air, and algae were weighted to assess their water loss during the emersion period. At the end of the series of measurements, algae were rehydrated to assess their fresh weight (FW) and then dried for $48 \mathrm{~h}$ at $60^{\circ} \mathrm{C}$ to assess their dry weight (DW). Fluxes were expressed as $\mu \mathrm{mol}$ $\mathrm{C} \mathrm{g}_{\mathrm{DW}}{ }^{-1} \mathrm{~h}^{-1}$. The relative tissue water content at time $\mathrm{t}$ was calculated as the percent of total water content: $\left[\left(W_{t}-D W\right) /(F W-D W)\right] \times 100$ (where $W_{t}$ represents the weight measured at time $\left.t\right)$. Productivity was assessed at the community scale during emersion using benthic chambers as described in Crowe et al. (2013). Three chambers were haphazardly-positioned (approximately $2 \mathrm{~m}$ apart) to account for spatial variability in each zone. Each chamber (of a total volume of $18.9 \mathrm{~L}$ ) was made of a transparent Perspex dome with a $0.3 \times 0.3 \mathrm{~m}$ transparent Perspex base air-tightly sealed with neutral silicon to the substratum. Changes in $\mathrm{CO}_{2}$ mol fraction in the air were measured by an infrared $\mathrm{CO}_{2}$ gas analyser (LiCor $\mathrm{Li}-800$ ). $\mathrm{CO}_{2}$ fluxes were estimated following the same procedure as described for single species measurements. The benthic chambers were opened between two consecutive incubations to renew the ambient air. In the Fucoid zones, algae were collected at the end of the series of measurements, and the zone-forming algae were dried for $48 \mathrm{~h}$ at $60^{\circ} \mathrm{C}$ and weighted. In the Laminaria digitata zone, there was no individual of the zone forming species inside the chambers. Incubations were performed either in ambient light conditions to assess the net productivity (NP) or in dark (after the chamber has been covered with an opaque tarp) in order to assess the respiration (R) rate. The gross productivity (GP) was then calculated by correcting NP by R.

\subsection{Data analyses}

To compare the photosynthetic activity and the productivity of the different species measured at the different scales at the two seasons and sites, the highest electron transport rates (ETR) and the highest carbon fluxes obtained at each occasion under emersion or immersion either in ambient light (mean PAR values given in Table 1) or in darkness were selected. Care was taken to use measurements performed in ambient light at saturating irradiance levels. A threshold of $300 \mu \mathrm{mol}$ photons $\mathrm{m}^{-2} \mathrm{~s}^{-1}$ was chosen based on the average value of $291 \mu \mathrm{mol}$ photons $\mathrm{m}^{-2} \mathrm{~s}^{-1}$ given for the onset of light saturation of coastal macroalgal communities by Middelboe et al. (2006). For under 
emersion measurements, care was also taken to use measures obtained during the early stages of emersion on still hydrated algae (relative tissue water content between 72 and $97 \%$ for individual scale measurements). Some measurements could not be achieved under immersion due to the difficulty of working while diving in the backwash of the intertidal zone and some data are thus missing. The effect of site and season on the results obtained for each target species was tested when no data were missing using the Scheirer-Ray-Hare H-test (non-parametric 2-way ANOVA).

\section{Results}

\subsection{Photosynthetic activity and productivity under emersion}

Mean ETR was greatly higher for P. canaliculata than for L. digitata at each site and season (between 9 and 16 times higher, Fig 1.A). There was no significant difference according to the season or site for P. canaliculata (Table 2). For L. digitata, mean ETR was significantly higher in spring than summer but there was no significant difference according to the site (Table 2).

The gross productivity rate was also higher for $P$. canaliculata than for L. digitata at each site and season (more than 2 times higher, Fig 2.C). For L. digitata, respiration rates were sometimes higher than gross productivity leading to positive carbon fluxes in the benthic chamber under light at Wimereux in summer and in both seasons at Roscoff (Fig 2.A).

The mean gross productivity rate measured at the community scale was higher for the $P$. canaliculata zone than the L. digitata zone at Wimereux at the two seasons (between 3 and 4 times higher) while the order of magnitude was the same for the two zones at Roscoff at the two seasons (Fig 3.C). At this scale, carbon fluxes in the benthic chambers under light were always negative, i.e. gross productivity rates were higher than respiration rates. Mean gross productivity rates measured on the L. digitata zone were significantly higher at Roscoff than at Wimereux but there were no significant differences according to the season (Table 2). There were no significant differences according to the season or site for $P$. canaliculata (Table 2). The mean biomass of $P$. canaliculata (Table 3 ) was 
significantly lower at Wimereux than Roscoff but there were no significant differences between seasons (Table 2).

\subsection{Photosynthetic activity and productivity under immersion}

The mean ETR measured during immersion was greater for $L$. digitata than for $P$. canaliculata at Roscoff in summer, the single occasion when ETR was measured under water for both species (Fig 1.B).

At the individual scale, measurements under dark could be achieved only in three experiments (Fig 2 . $E$ ), leading to only three available values of gross productivity (the highest being for $P$. canaliculata and the lowest for L. digitata, Fig 2.F). More experiments could be achieved under light, allowing the comparison of the net productivity rates. They were of the same order of magnitude for $P$. canaliculata than L. digitata at Roscoff in summer, the single occasion when NP was measured under water for both species (Fig 2.D).

\subsection{Under emersion versus under immersion photosynthetic activity and productivity}

The electron transport rate was higher in air than underwater for $P$. canaliculata and $F$. spiralis (the ratio reaching 3.72) but lower for F. serratus and L. digitata (the ratio reaching 0.14 ). For $P$. canaliculata, the higher ETR in the air was explained by the greater photon flux density in the air than underwater at Wimereux in spring (Table 1, while the effective quantum yield of photosystem II was 0.5 and 0.7 in air and water respectively), but was also due to a greater $\Phi_{\text {PSII }}$ in the air at Roscoff in summer (0.6 versus 0.4$)$. For $F$. spiralis, it was mainly due to a greater $\Phi_{\text {PSII }}$ in the air (0.5 versus 0.2 ). Particularly low values of $\Phi_{\text {PSII }}(<0.1)$ were measured for $L$. digitata under emersion at Roscoff while they were between 0.2 and 0.7 in the other cases. The ratio of individual scale net productivity in air versus water was lower than 1 at each occasion (the maximum was 0.95 for $F$. spiralis) and was even negative for L. digitata at Roscoff (due to respiration rates higher than gross productivity under emersion). The ratio of gross productivity in air versus water was also lower than 1 in the only three occasions it could be calculated. 


\section{Discussion}

The present study of the photosynthetic performance of intertidal macroalgae based on in situ measurements emphasizes on a major result: the trends observed under emersion according to the position of the algae along the shore vary with the scale of measurements. The uppermost species Pelvetia canaliculata had higher photosynthetic activity and productivity under emersion than the lowermost species Laminaria digitata, while the few available data showed no trend between the zone-forming species under immersion. Futhermore, the photosynthetic activity measured at the thallus scale was higher in air than underwater for the uppermost species and lower in air than underwater for the lowermost species. Differences between zone-forming species were, however, greatly reduced when measurements were scaled up from the electron transport rate of thallus to the gross productivity of individuals and communities.

\subsection{Photosynthetic performance according to the shore-level of the algae}

In the present study, carbon flux measured at the individual scale, both under immersion and emersion, in ambient light conditions (with PAR $>300 \mu \mathrm{mol}$ photons $\mathrm{m}^{-2} \mathrm{~s}^{-1}$ ) suggested that photosynthetic performance was higher underwater whatever the species was, for both sites and seasons and even if the emerged individuals were not significantly dehydrated (relative tissue water content $>72 \%$ ). Furthermore, a net negative productivity (respiration higher than gross productivity) was observed for L. digitata under emersion. However, the difference between underwater and aerial performance was lower for upper species, with a $\mathrm{NP}_{\mathrm{em}} / \mathrm{NP}_{\mathrm{im}}$ ratio as high as 0.95 for Fucus spiralis. At the thallus scale, the electron transport rate also measured both under immersion and emersion in ambient light conditions was higher in air for $P$. canaliculata and $F$. spiralis but higher underwater for Fucus serratus and L. digitata. Moreover, at that scale of measurement, the upper species on the shore had by far the highest photosynthetic activity under emersion and the lower species had the lowest. This obvious trend was observed independently of the season or site and could not be only explained by better light conditions during measurements for upper species. 
Some previous laboratory researches, made under controlled light conditions and based on either oxygen and carbon flux (Johnson et al., 1974; Kawamitsu and Boyer, 1999) or fluorescence (Skene, 2004) measurements on thalli, also suggested that the ability of intertidal algae for sustained photosynthesis in air is enhanced for upper shore species. Johnson et al. (1974) even obtained a $\mathrm{NP}_{\mathrm{em}} / \mathrm{NP}_{\mathrm{im}}$ ratio of 6.6 for the high-shore species Fucus distichus. This trend might be explained by the significant ecophysiological distinctions that had been made between algae living essentially completely submersed and those spending a part of tidal cycles in the emersed state. The upper shore algae had been shown to have the potential for rapid photosynthesis in air during the short time without desiccation (Surif and Raven, 1990). Thus, the less time is available for photosynthesis, as limited by desiccation, the greater is the photosynthetic rate during the time available. The " $\mathrm{CO}_{2}$ concentrating mechanism", characteristic of photosynthesis in the eulittoral Fucaceae (Surif and Raven, 1989), may be important in increasing the efficiency of emersed photosynthesis with limited capital of water available.

Some contrasting results have, however, been obtained in laboratory studies. For example, the carbon intake in the air was higher for the lower shore Saccharina latissima than the uppershore Pelvetia canaliculata (Ni Longphuirt et al., 2013), the photosynthesis rates of intertidal Fucoids were always higher in water than in air (Williams and Dethier, 2005) or either higher in water or in air according to the temperature (Madsen and Maberly, 1990) and the effective PSII quantum efficiency of Laminaria digitata increased after 3h of emersion (Nitschke et al., 2011). Furthermore, the effect of short-term emersion on chl $a$ fluorescence responses to irradiance has been shown to be dependent on the protocol used for the acclimation of the algae to the different light levels (Nitschke et al., 2012) and the variation of the effective PSII quantum efficiency measured in situ has been shown to be dependent on the meteorological conditions (Lamote et al., 2012). Different sampling, keeping and/or measuring conditions could then have influenced both laboratory and field results, leading to various conclusions among studies. 


\subsection{Variation in the trends of photosynthetic performance according to the scale of}

measurements

The trend of photosynthetic activity under emersion according to the shore-level of the algae was obvious in the present study when photosynthetic activity was measured at the thallus scale as electron transport rate. When photosynthetic activity was measured as gross productivity at the individual scale, it was also typically higher for the uppermost than the lowermost species but the trend along the shore was less obvious (even if the lack of replication prevents clear comparisons to be performed). Finally, when photosynthetic activity was measured as gross productivity at the community scale, which is a more relevant ecological unit, the highest rates were measured on the intermediate mid-shore zones and, at one of the two sites, rates were higher for the lowermost zone than for the uppermost zone. Furthermore, considering the whole set of data the coefficient of variation of net productivity under emersion was 1.15 at the individual scale and 0.55 at the community scale.

The contrasting results using either fluorescence or carbon flux measurements can suggest that thalli are not relevant ecological units but also that the photosystem II activity measured as ETR is not always a relevant measure of the rate of photosynthesis. There is a general assumption that a linear relationship between ETR and gross photosynthesis exists, as long as environmental stresses do not impose restrictions on photosynthetic carbon fixation. The linearity between ETR and photosynthesis of macroalgae has been, however, only confirmed at low light intensities (Enriquez and Borowitzka, 2010). ETR calculation is based on the assumption that light absorption is only due to photosynthetic pigments. There are, however, alternative electron sinks (e.g. the Mehler reaction, the photorespiration) which explain the deviation from linearity in the relationship between ETR and gross productivity (measured either as $\mathrm{O}_{2}$ production or $\mathrm{C}$ uptake) observed at high irradiances in various primary producers (Beardall et al., 2009). This occurred as critical low values of $\Phi_{\text {PSII }}$ were reached and the irradiance at which these values were reached depended on the previous light histories undergone by the algae (Beer and Axelsson, 2004). It is the irradiance relative to the algal 
growth conditions rather than the irradiance during the measurement that determines the threshold. Beer and Axelsson (2004) measured critical values of $\Phi_{\text {PSII }}(<0.1)$ at lower irradiance for Laminaria saccharina than for Fucus serratus ( 250 versus $2000 \mu$ mol photons $\mathrm{m}^{-2} \mathrm{~s}^{-1}$ ) while both species were acclimated to $400 \mu \mathrm{mol}$ photons $\mathrm{m}^{-2} \mathrm{~s}^{-1}$ for two weeks. In the present study, critical low values of $\Phi_{\text {PSII }}$ were measured for Laminaria digitata under emersion at Roscoff. Such critical values were previously measured in situ underwater at ebb tide around midday on the Roscoff kelps L. saccharina and L. digitata. The response of $\Phi_{\text {PSII }}$ to high irradiances was associated to an increase in the nonphotochemical quenching and was explained as a down-regulation of the photosystem II (Gévaert et al., 2003; Delebecq et al., 2011).

The contrasting results measuring carbon fluxes either at the individual or at the community scale do reflect the difference in use of resources by either isolated or grouped individuals of only one species and by mixed communities allowing species to interact and supplement each other. Although individual photosynthesis must influence the community response, individual metabolism was not expected to be closely related to community metabolism, because this represents a complex integrated response of many different species exposed to a wide range of local light conditions within the canopies (Middelboe and Binzer, 2004; Binzer and Middelboe, 2005; Middelboe et al., 2006). Tait and Schiel (2011) showed that layering within macroalgal assemblages plays a major role in maintaining net photosynthesis throughout the natural range of irradiance and even enhances photosynthesis at high irradiance. Tait and Schiel (2010) measured the underwater productivity of three fucoid assemblages. The rates, on a per area basis, showed a down shore-height gradient explained by the greater biomass and number of algal species of the lower-shore assemblage. In the present study, a down shore-height gradient was also shown when measurements were performed on the three fucoid assemblages (i.e. at Wimereux in summer). The highest rates at the community scale were measured on the Fucus serratus zone where the biomass of the dominant canopy species and the number of species were the highest ( 9 species were identified inside the chambers while it was 7 for the Pelvetia canaliculata and 8 for the Fucus spiralis zones). The zone of Laminaria digitata 
had also a great algal biomass (it was measured only once, at Roscoff in summer, and was $80.51 \pm$

$26.62 \mathrm{~g} \mathrm{Dw} / 0.09 \mathrm{~m}^{2}$ ) and had a great species richness ( 9 and 22 species identified inside the chambers at Wimereux and Roscoff respectively) but lower community scale productivity under emersion, particularly at Wimereux. This certainly reflects the low efficiency in air of algae living essentially submersed. Further measurements should be performed at the community scale during immersion periods to test if the down shore-height gradient highlighted with fucoids is maintained when both fucoids and kelps are considered.

\section{Acknowledgements}

This work was funded by the French program EC2CO/INSU. Thierry Cariou from the Station Biologique de Roscoff provided surface PAR data that was useful for intercalibration between our various measures. Thanks are due to Marie-Andrée Janquin, Renaud Michel and Lucie Camañez for assistance in the field. We would like also to thank the Service Mer \& Observation from the Station Biologique de Roscoff for valuable support and particularly François Le Ven who managed to bring the wayfarer chamber back from the "Bigorneau langoureux" in the Batz Island. Finally, we acknowledge the improvements originated by the comments made by the editor and reviewers of this paper.

\section{Literature cited}

Beardall, J., Ihnken, S., Quigg, A., 2009. Gross and net primary production: closing the gap between concepts and measurements. Aquat. Microb. Ecol. 56, 113-122.

Beer, S., Axelsson, L., 2004. Limitations in the use of PAM fluorometry for measuring photosynthetic rates of macroalgae at high irradiances. Eur. J. Phycol. 39, 1-7.

Binzer, T., Middelboe, A.L., 2005. From thallus to communities: scale effects and photosynthetic performance in macroalgae communities. Mar. Ecol. Prog. Ser. 287, 65-75. 
Crowe, T.P., Cusson, M., Bulleri, F., Davoult, D., Arenas, F., Aspden, R., Benedetti-Cecchi, L., Bevilacqua, S., Davidson, I., Defew, E., Fraschetti, S., Golléty, C., Griffin, J.N., Herkuel, K., Kotta, J., Migné, A., Molis, M., Nicol, S.K., Noël, L.M.L.J., Pinto, I.S., Valdivia, N., Vaselli, S., Jenkins, S.R., 2013. Large-scale variation in combined impacts of canopy loss and disturbance on community structure and ecosystem functioning. PloS one 8, e66238.

Delebecq, G., Davoult, D., Menu, D., Janquin, M.-A., Migné, A., Dauvin, J.-C., Gévaert, F., 2011. In situ photosynthetic performance of Laminaria digitata (Phaeophyceae) during spring tides in Northern Brittany. Cah. Biol. Mar. 52, 405-414.

Dring, M.J., Brown, F.A., 1982. Photosynthesis of intertidal brown algae during and after periods of emersion: a renewed search for physiological causes of zonation. Mar. Ecol. Prog. Ser. 8, 301-308. Enriquez, S., Borowitzka, M.A., 2010, The use of the fluorescence signal in studies of seagrasses and macroalgae. In: Suggett, D.J., Prasil, O., Borowitzka, M.A. (Eds.), Chlorophyll a fluorescence in aquatic sciences: methods and applications. Springer, pp. 187-208.

Genty, B., Briantais, J.-M., Baker, N.R., 1989. The relationship between the quantum yield of photosynthetic electron transport and quenching of chlorophyll fluorescence. Biochim. Biophys. Acta 990, 87-92.

Gévaert, F., Créach, A., Davoult, D., Migné, A., Levavasseur, G., Arzel, P., Holl, A.-C., Lemoine, Y., 2003. Laminaria saccharina photosynthesis measured in situ: photoinhibition and xanthophyll cycle during a tidal cycle. Mar. Ecol. Prog. Ser. 247, 43-50.

Gévaert, F., Delebecq, G., Menu, D., Brutier, L., 2011. A fully automated system for measurements of photosynthetic oxygen exchange under immersed conditions: an example of its use in Laminaria digitata (Heterokontophyta: Phaeophyceae). Limnol. Oceanogr. Meth. 9, 361-379. Johnson, W.S., Gigon, A., Gulmon, S.L., Mooney, H.A., 1974. Comparative photosynthetic capacities of intertidal algae under exposed and submerged conditions. Ecology 55, 450-453. Kawamitsu, Y., Boyer, J.S., 1999. Photosynthesis and carbon storage between tides in a brown alga, Fucus vesiculosus. Mar. Biol. 133, 361-369. 
Lamote, M., Johnson, L.E., Lemoine, Y., 2012. Photosynthetic responses of an intertidal alga to emersion: the interplay of intertidal height and meteorological conditions. J. Exp. Mar. Biol. Ecol. 428, $16-23$.

Madsen, T.V., Maberly, S.C., 1990. A comparison of air and water as environments for photosynthesis by the intertidal alga Fucus spiralis (Phaeophyta). J. Phycol. 26, 24-30.

Mann, K.H., 1973. Seaweeds: their productivity and strategy for growth. Science 182, 975-981.

Middelboe, A.L., Binzer, T., 2004. Importance of canopy structure on photosynthesis in single- and multi-species assemblages of marine macroalgae. Oikos 107, 422-432.

Middelboe, A.L., Sand-Jensen, K., Binzer, T., 2006. Highly predictable photosynthetic production in natural macroalgal communities from incoming and absorbed light. Oecologia 150, 464-476.

Migné, A., Davoult, D., Spilmont, N., Menu, D., Boucher, G., Gattuso, J.-P., Rybarczyk, H., 2002. A closed-chamber $\mathrm{CO}_{2}$-flux method for estimating intertidal primary production and respiration under emersed conditions. Mar. Biol. 140, 865-869.

Millero, F.J., Zhang, J.-Z., Lee, K., Campbell, D.M., 1993. Titration alkalinity of seawater. Mar. Chem. $44,153-165$

Ni Longphuirt, S., Eschmann, C., Russell, C., Stengel, D., 2013. Seasonal and species-specific response of five brown macroalgae to high atmospheric CO2. Mar. Ecol. Prog. Ser. 493, 91-102.

Nitschke, U., Connan, S., Stengel, D.B., 2012. Chlorophyll a fluorescence responses of temperate Phaeophyceae under submersion and emersion regimes: a comparison of rapid and steady-state light curves. Photosyn. Res. 114, 29-42.

Nitschke, U., Ruth, A.A., Dixneuf, S., Stengel, D.B., 2011. Molecular iodine emission rates and photosynthetic performance of different thallus parts of Laminaria digitata (Phaeophyceae) during emersion. Planta 233, 737-748.

Oviatt, C.A., Rudnick, D.T., Keller, A.A., Sampou, P.A., Almquist, G.T., 1986. A comparison of system $\left(\mathrm{O}_{2}\right.$ and $\left.\mathrm{CO}_{2}\right)$ and $\mathrm{C}-14$ measurements of metabolism in estuarine mesocosms. Mar. Ecol. Prog. Ser. $28,57-67$. 
Quadir, A., Harrison, P.J., Dewreede, R.E., 1979. Effects of emergence and submergence on the photosynthesis and respiration of marine macrophytes. Phycologia 18, 83-88.

Skene, K.R., 2004. Key differences in photosynthetic characteristics of nine species of intertidal macroalgae are related to their position on the shore. Can. J. Bot. 82, 177-184.

Strickland, J.D.H., Parsons, T.R., 1972. A practical handbook of seawater analysis. Bull. Fish. Res. Bd Can. 167, 1-311.

Surif, M.B., Raven, J.A., 1989. Exogenous inorganic carbon sources for photosynthesis in seawater by members of the Fucales and the Laminariales (Phaeophyta): ecological and taxonomic implications. Oecologia 78, 97-105.

Surif, M.B., Raven, J.A., 1990. Photosynthetic gas exchange under emersed conditions in eulittoral and normally submersed members of the Fucales and the Laminariales: interpretation in relation to $\mathrm{C}$ isotope ratio and $\mathrm{N}$ and water use efficiency. Oecologia $82,68-80$.

Tait, L.W., Schiel, D.R., 2010. Primary productivity of intertidal macroalgal assemblages: comparison of laboratory and in situ photorespirometry. Mar. Ecol. Prog. Ser. 416, 115-125.

Tait, L.W., Schiel, D.R., 2011. Dynamics of productivity in naturally structured macroalgal assemblages: importance of canopy structure on light-use efficiency. Mar. Ecol. Prog. Ser. 421, 97107.

Williams, S.L., Dethier, M.N., 2005. High and dry: variation in net photosynthesis of the intertidal seaweed Fucus gardneri. Ecology 86, 2373-2379. 
Figure 1: Highest electron transport rate (ETR in $\mu$ mol e $\mathrm{m}^{-2} \mathrm{~s}^{-1}$, mean $\pm s d, n=3$ ) measured in ambient light (PAR values given in table 1) on thalli of the different zone-forming species (Pc: Pelvetia canaliculata, Fsp: Fucus spiralis, Fse: Fucus serratus, Ld: Laminaria digitata) at the two sites (Wx:

Wimereux, Ro: Roscoff) and seasons (Su: summer, Sp: spring) under emersion (Em, A) and immersion (Im, B).

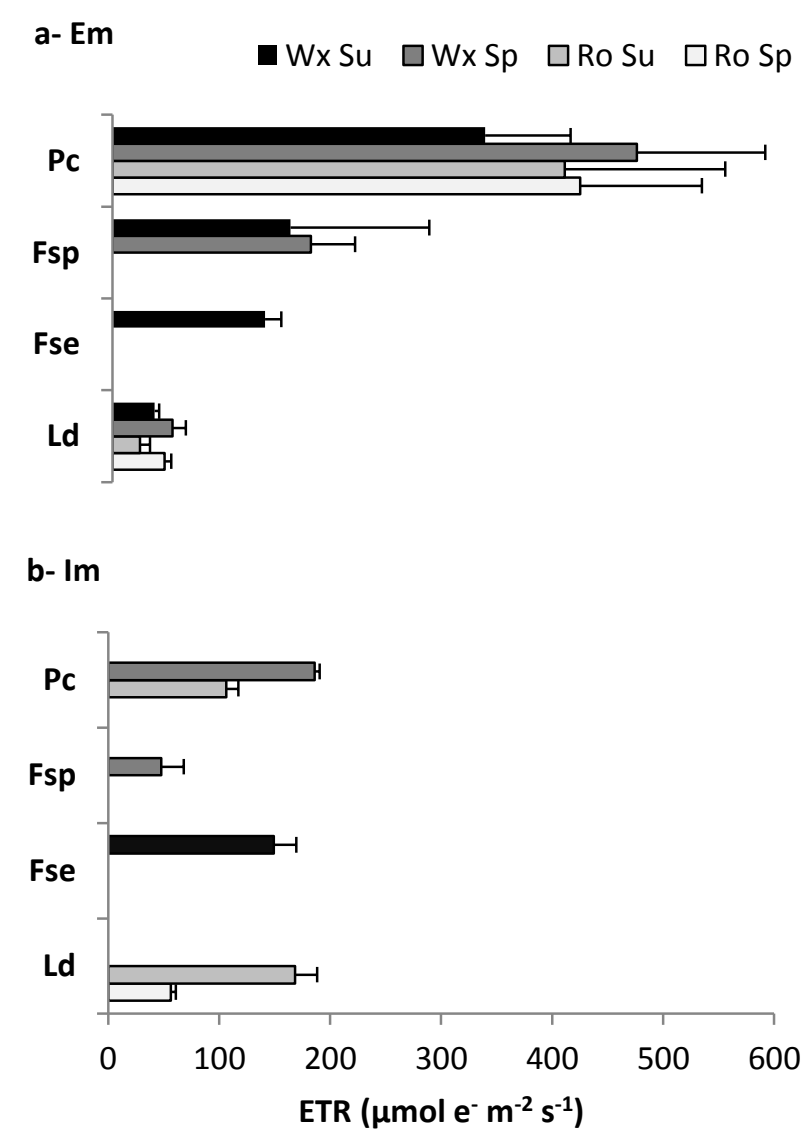


Figure 2: Highest carbon fluxes measured in the benthic chamber at the individual scale (in $\mu \mathrm{mol} C$ $\mathrm{gDW}^{-1} \mathrm{~h}^{-1}$ ) in ambient light (A and D, PAR values given in table 1 ) or in dark ( $B$ and $E$ ) on the different zone-forming species (Pc: Pelvetia canaliculata, Fsp: Fucus spiralis, Fse: Fucus serratus, Ld: Laminaria digitata) at the two sites (Wx: Wimereux, Ro: Roscoff) and seasons (Su: summer, Sp: spring) and corresponding gross productivity (GP, C and F) under emersion ( $\mathrm{Em}, \mathrm{A}, \mathrm{B}$ and $\mathrm{C}$ ) and immersion (Im, $D, E$ and $F)$.
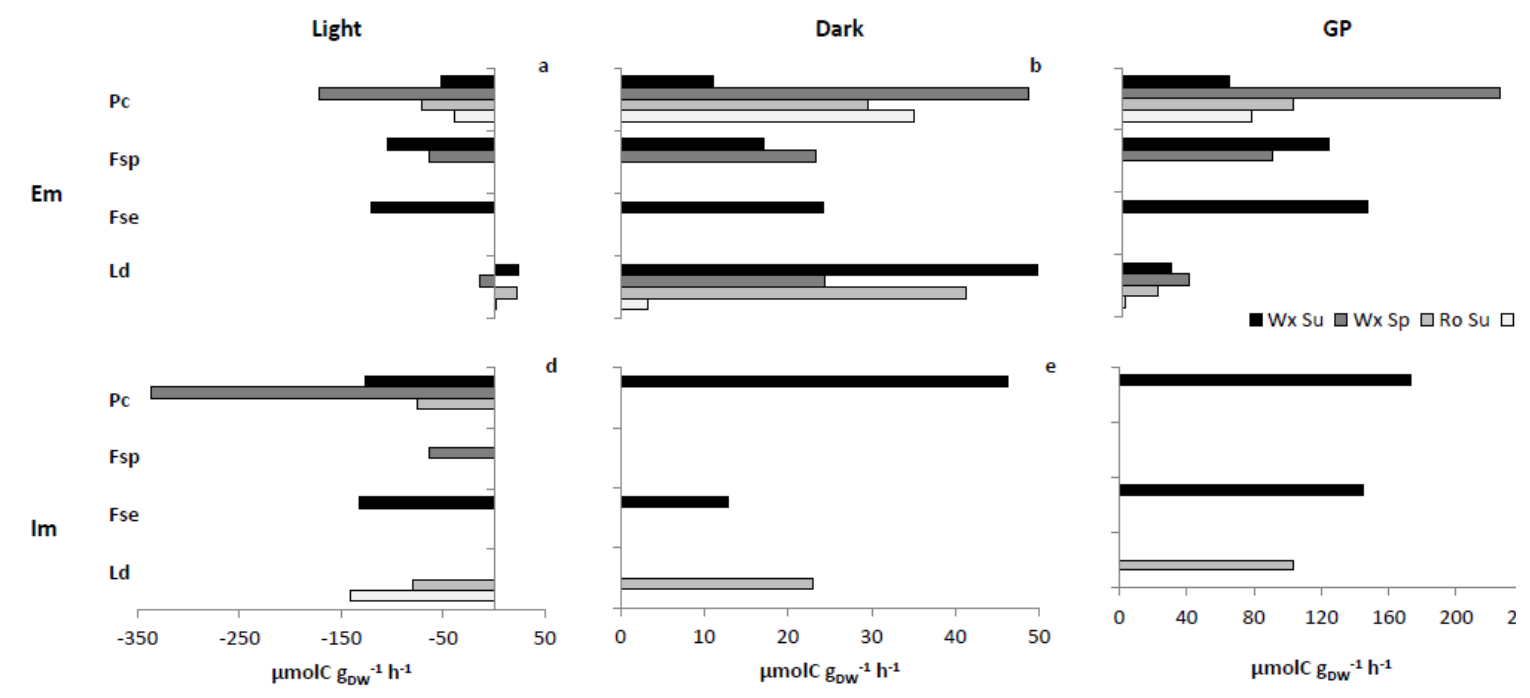
Figure 3: Highest carbon fluxes measured under emersion in the benthic chambers at the community scale (in mmol $\mathrm{C} \mathrm{m}^{-2} \mathrm{~h}^{-1}$, mean $\pm s d, n=3$ ) in ambient light ( $\mathrm{a}$, PAR values given in table 1 ) or in dark (b) for the different zone-forming species (Pc: Pelvetia canaliculata, Fsp: Fucus spiralis, Fse: Fucus serratus, Ld: Laminaria digitata) at the two sites (Wx: Wimereux, Ro: Roscoff) and seasons (Su: summer, Sp: spring) and corresponding gross productivity (GP, c).
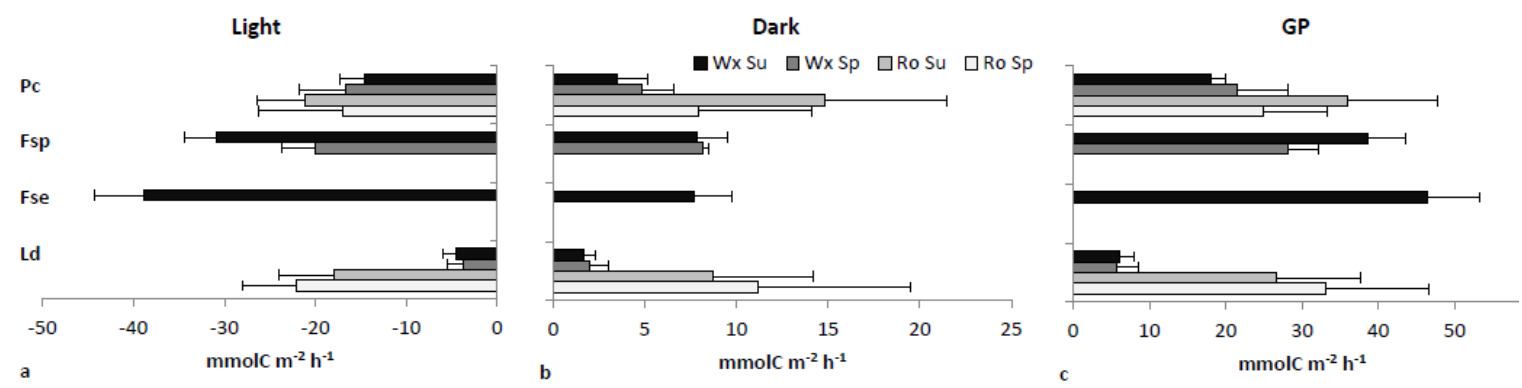
Table 1: Light condition (mean PAR and standard deviation in $\mu$ mol photons $\mathrm{m}^{-2} \mathrm{~s}^{-1}$ ) during measurements of the highest electron transport rates (ETR) and net productivities (as carbon fluxes) at individual scale (NP) and community scale (NCP) on the different zone forming species (Pc: Pelvetia canaliculata, Fsp: Fucus spiralis, Fse: Fucus serratus, Ld: Laminaria digitata) at the two sites (Wx:

Wimereux, Ro: Roscoff ) and seasons (Su: summer, Sp: spring) under emersion (Em) and immersion (Im).

\begin{tabular}{|c|c|c|c|c|c|c|c|c|c|c|c|c|}
\hline \multirow[b]{2}{*}{ Species } & \multirow[b]{2}{*}{ Site } & \multirow[b]{2}{*}{ Season } & \multicolumn{2}{|c|}{ ETR Em } & \multicolumn{2}{|l|}{ ETR Im } & \multicolumn{2}{|l|}{ NP Em } & \multicolumn{2}{|l|}{ NP Im } & \multicolumn{2}{|l|}{ NCP Em } \\
\hline & & & mean PAR & sd & mean PAR & sd & mean PAR & sd & mean PAR & sd & mean PAR & sd \\
\hline \multirow[t]{4}{*}{ Pc } & $W x$ & Su & 1650 & 21 & & & 1359 & 14 & 1018 & 85 & 1361 & 13 \\
\hline & & $\mathrm{Sp}$ & 2023 & 1 & 574 & 1 & 630 & 46 & 611 & 69 & 2022 & 12 \\
\hline & Ro & Su & 2328 & 259 & 390 & 38 & 1995 & 387 & 466 & 36 & 1231 & 585 \\
\hline & & Sp & 1798 & 152 & & & 1276 & 293 & & & 1551 & 104 \\
\hline \multirow[t]{2}{*}{ Fsp } & $W x$ & $\mathrm{Su}$ & 1183 & 43 & & & 711 & 446 & & & 1126 & 439 \\
\hline & & Sp & 740 & 1 & 597 & 104 & 898 & 68 & 347 & 58 & 1302 & 65 \\
\hline Fse & $W x$ & Su & 476 & 5 & 970 & 227 & 434 & 34 & 327 & 60 & 431 & 35 \\
\hline \multirow[t]{4}{*}{ Ld } & $W x$ & $\mathrm{Su}$ & 315 & 5 & & & 412 & 32 & & & 520 & 13 \\
\hline & & $\mathrm{Sp}$ & 655 & 4 & & & 389 & 52 & & & 702 & 23 \\
\hline & Ro & $\mathrm{Su}$ & 1933 & 1002 & 676 & 83 & 2248 & 439 & 905 & 206 & 1942 & 260 \\
\hline & & Sp & 1441 & 0 & 330 & 23 & 1024 & 72 & 1269 & 122 & 1395 & 105 \\
\hline
\end{tabular}


Table 2: Significance of the effect of season and site on electron transport rates (ETR) and gross community productivity (GCP) measured under emersion and on dry weight inside benthic chambers (DW) of the zone-forming species (Pc: Pelvetia canaliculata, Ld: Laminaria digitata) as tested by Scheirer-Ray-Hare H-test.

\begin{tabular}{cclcc} 
Variable & Zone-forming species & Factor & H & p-value \\
\hline \multirow{2}{*}{ ETR } & Pc & Season & 1.256 & 0.262 \\
& & Site & 0.026 & 0.872 \\
& & Interaction & 0.641 & 0.423 \\
\cline { 2 - 5 } & \multirow{2}{*}{ Ld } & Season & 8.308 & $\mathbf{0 . 0 0 4}$ \\
& & Site & 1.256 & 0.262 \\
& & Interaction & 0.103 & 0.748 \\
\hline \multirow{2}{*}{ GCP } & Pc & Season & 0.410 & 0.522 \\
& & Site & 2.564 & 0.109 \\
& & Interaction & 1.256 & 0.262 \\
\cline { 2 - 5 } & \multirow{2}{*}{ Ld } & Season & 0.026 & 0.872 \\
& & Site & 8.308 & $\mathbf{0 . 0 0 4}$ \\
& & Interaction & 0.103 & 0.748 \\
\hline \multirow{2}{*}{ DW } & Pc & Season & 0.923 & 0.337 \\
& & Site & 7.410 & $\mathbf{0 . 0 0 6}$ \\
& & Interaction & 0.103 & 0.748 \\
\hline
\end{tabular}


Table 3: Mean dry weight (DW) and standard deviation ( $s d, n=3)$ of the zone-forming species (Pc: Pelvetia canaliculata, Fsp: Fucus spiralis, Fse: Fucus serratus) inside the benthic chambers used for the community scale fluxes measurements (surface area $=0.09 \mathrm{~m}^{2}$ ) performed at the two sites $(\mathrm{Wx}$ : Wimereux, Ro: Roscoff) and seasons (Su: summer, Sp: spring). There was no Laminaria digitata inside the benthic chambers during measurements performed in the L. digitata zones.

\begin{tabular}{ccccc} 
zone-forming species & site & season & mean DW (g) & sd \\
\hline Pc & Wx & Su & 21.01 & 12.36 \\
& & Sp & 14.86 & 4.03 \\
& Ro & Su & 65.25 & 14.56 \\
& & Sp & 44.63 & 17.27 \\
Fsp & Wx & Su & 50.32 & 12.98 \\
& & Sp & 42.78 & 16.34 \\
Fse & Wx & Su & 87.21 & 9.01
\end{tabular}

